\title{
CONTROL PROCESS ABSOLUTE STABILITY ANALYSIS OF CHARGE-DISCHARGE DEVICE WITH LOAD CONVERTER IN CONSTANT POWER MODE
}

\author{
E. A. Kopylov*, D. K. Lobanov, E. A. Mizrakh \\ Reshetnev Siberian State University of Science and Technology \\ 31, Krasnoyarsky Rabochy Av., Krasnoyarsk, 660037, Russian Federation \\ *E-mail: evgesh72@mail.ru
}

To reduce life time testing period of lithium-ion accumulator (LIA) special dynamic stress test (DST) is widely used. Lithium-ion accumulator dynamic stress test requires automatic charge-discharge devices (CDD) which provides necessary DST technological parameters with required precision. Authors developed charge-discharge devices with load converters (CDD-LC), which allow to reproduce required charge-discharge modes of high-power LIA automatically.

LIA cyclic charge-discharge with constant power pulses is the most difficult mode of DST. In this case, control system became nonlinear and time variant due to computation of signal power as multiply of LIA voltage and current.

Authors studied mathematical model of electromagnetic processes of CDD-LC in LIA power stabilization mode, formulated requirements to power stabilization control loop quality parameters, synthesized correction devices providing necessary control quality, studied CDD-LC control process absolute stability with Naumov-Tsypkin in LIA power stabilization and regulation modes.

Keywords: lithium-ion accumulator, capacity, power, charge-discharge, control system, load converter, correction device, absolute stability.

Сибирский журнал науки и технологий. 2018. Т. 19, № 2. С. 281-292

\section{АНАЛИЗ АБСОЛЮТНОЙ УСТОЙЧИВОСТИ ПРОЦЕССОВ УПРАВЛЕНИЯ ЗАРЯДНО-РАЗРЯДНЫМ УСТРОЙСТВОМ С НАГРУЗОЧНЫМ ПРЕОБРАЗОВАТЕЛЕМ В РЕЖИМЕ СТАБИЛИЗАЦИИ МОЩНОСТИ}

\author{
Е. А. Копылов*, Д. К. Лобанов, Е. А. Мизрах \\ Сибирский государственный университет науки и технологий имени академика М. Ф. Решетнева \\ Российская Федерация, 660037, г. Красноярск, просп. им. газ. «Красноярский рабочий», 31 \\ *E-mail: evgesh72@mail.ru
}

\begin{abstract}
Для сокращения сроков ресурсных испьтаний литий ионных аккумуляторов (ЛИА) применяют методики динамического стрессового тестирования (ДСТ). Для проведения ДСТ ЛИА необходимы автоматические зарядноразрядные устройства (ЗРУ), обеспечивающие с заданной точностью требуемые параметры технологических режимов ДСТ ЛИА. Разработаны зарядно-разрядные устройства с нагрузочным преобразователями (НП), позволяющими автоматически воспроизводить требуемые режимы заряда-разряда ЛИА большой емкости.

Наиболее сложным режимом является циклический заряд-разряд ЛИА импульсами постоянной мощности разной величины и длительности. В этом случае система управления ЗРУ становится нестационарной нелинейной вследствие того, что мощчость сигнала вычисляется как произведение тока на напряжение ЛИА.

Рассмотрена математическая модель электромагнитных процессов ЗРУ-НП в режиме стабилизаџии мощцнсти заряда-разряда ЛИА, сформулированы требования к показателям качества управления контура стабилизачии мощности, проведен синтез корректирующих устройств, обеспечивающих требуемое качество управления, исследована по методу Наумова-Цыпкина абсолютная устойчивость процессов управления ЗРУ-НП в режимах регулирования и стабилизаџии мощности заряда-разряда ЛИА.
\end{abstract}

Ключевые слова: литий-ионный аккумулятор, ёмкость, мощность, заряд-разряд, система управления, нагрузочный преобразователь, корректирующее устройство, абсолютная устойчивость.

Doi: 10.31772/2587-6066-2018-19-2-281-292

\section{Nomenclature}

$I a^{*}$

$I L 2 *$

$K C S$
Boost converter input current in point of linear decomposition

Reactor L2 current in point of linear decomposition

Current sensor transfer ratio

KVS
$K V S a$
$n$
$U a *$

$U$ in $^{*} F B$

Second voltage sensor transfer ratio Accumulator voltage sensor transfer ratio Transformer ratio Accumulator voltage in point of linear decomposition Full-bridge converter input voltage in point of linear decomposition 
Wfb PS $(s) \quad$ Feedback loop transfer function of power source

WOL_V(s) Open voltage loop transfer function

WOL_P(s) Open power loop transfer function

$\operatorname{WPS}(s) \quad$ Open power source loop transfer function

$W P(s) \quad$ Power regulator transfer function

WPWM1(s) Power controller PWM transfer function

WPWM2(s) Voltage controller PWM transfer function

$W U(s) \quad$ Voltage regulator transfer function

$\mathrm{Za}(\mathrm{s}) \quad$ Accumulator impedance

Zload (s) Load impedance

ZPS (s) Power source impedance

$\triangle I a \quad$ Increment of accumulator current

$\triangle$ Iin_FB Increment of full-bridge converter input current

$\triangle I L 2 \quad$ Increment of reactor L2 current

$\Delta \operatorname{Iload}(s) \quad$ Increment of load current

$\Delta U a(s) \quad$ Increment of accumulator voltage

$\Delta U$ a Idl Increment of accumulator idling voltage

$\Delta$ Uin Increment of boost converter input voltage

$\triangle U$ Uin_FB Increment of full-bridge converter input voltage

$\triangle U r e f F B(s)$ Increment of full-bridge converter reference voltage

$\Delta U$ load(s) Increment of load voltage

$\triangle U P S(s) \quad$ Increment of power source voltage

$\triangle U r e f P S(s) \quad$ Increment of power source reference voltage

$\triangle P(s) \quad$ Increment of accumulator power

$\Delta \operatorname{Pref}(s) \quad$ Increment of power controller reference power

$\Delta \gamma 1(s) \quad$ Increment of boost converter duty cycle

$\Delta \gamma 2(s) \quad$ Increment of full-bridge converter duty cycle

$\gamma 1^{*} \quad$ Boost converter duty cycle in point of linear $\gamma 2 *$ decomposition

Full-bridge converter duty cycle in point of linear decomposition

Introduction. Reducing life time testing period of LIA can significantly accelerate and reduce the cost of design and development of lithium-ion accumulator battery (LIAB) and electrical power system (EPS) of spacecraft. To reduce life time testing period of LIA, standards are developed: GOST R IEC 62660-1-2014, GOST R IEC 61427-1-2014 [1; 2], in which the LIA life time tests are based on the dynamic stress testing (DST) method. Reduction of the terms for life time tests with DST is achieved by increasing the values of the attributes (constant current, voltage and capacity) of the charge / discharge up to the maximum values set by the manufacturer.

To automate the electrical tests of LIA, including life time tests with DST, the authors developed a chargedischarge device with a load converter (CDD-LC) [3-7] with a pulse-width method of regulation, which due to the original topology of the LC [3-7], has the following advantages in comparison with the known ones [8-12]:

- the possibility of providing the required values of the attributes of the DST LIA of a large capacity;

- extended range of testing currents of LIA (0.1 A-160 A);

- the possibility of LC power surplus recuperation in a direct current network of an uninterruptible power supply.

CDD-LC [3-7] in the regime of charge / discharge LIA power stabilization can be represented as two interconnected control loops: the power stabilization loop and the input voltage stabilization loop of the bridge transformer converter (BTC).

The questions of static and dynamic analysis and synthesis of CDD-LC with stabilization of charge/discharge LIA current are considered in $[13 ; 14]$. In this case, pulsed electromagnetic processes in CDD-LC are described by continuous differential equations, which is possible on the basis of Kotelnikov-Shannon sampling theorem [15; 16].

The most complicated mode of DST is the cyclic charge-discharge of LIA by pulses of constant power of different magnitude and duration. In this case, the power management system of the CDD becomes time variant nonlinear, because the charge / discharge power is calculated as the product of the current by the voltage of LIA. The charge / discharge power of LIA at DST varies over a wide range and, accordingly, the nonlinear characteristic of the CDD-LC is regulated, which requires an investigation of the control system absolute stability.

Let us consider the stability of each stabilization loop.

Power stabilization loop. According to the structural scheme $[7 ; 13 ; 14]$, the block diagram (fig. 1) and the equivalent scheme [13], the electromagnetic processes in the mode of CDD-LC charge power stabilization can be described by the following systems of differential equations:

$$
\begin{aligned}
& \left(\Delta U_{P S}(s)=\left(\Delta U_{r e f_{-} P S}(s)-\Delta U_{i n}(s) \cdot W_{f b_{-} P S}(s)\right) \times\right. \\
& \times W_{P S}(s)-Z_{P S}(s) \cdot \Delta I_{a}(s) \text {, } \\
& \Delta U_{\text {in }}(s)=\Delta U_{P S}(s)-\Delta U_{a}(s)-Z_{a}(s) \cdot \Delta I_{a}(s), \\
& \Delta \gamma_{1}(s)=\Delta P_{\varepsilon}(s) \cdot K_{C S} \cdot K_{V S a} \cdot W_{P}(s) \cdot W_{P W M 1}(s), \\
& \Delta \gamma_{2}(s)=\Delta U_{\varepsilon}(s) \cdot K_{V S} \cdot W_{U}(s) \cdot W_{P W M 2}(s) \text {, } \\
& \Delta U_{\text {in }{ }_{-} F B}(s)=\Delta U_{i n}(s)-\Delta I_{a}(s) \cdot\left(R_{L 1}+L_{L 1} \cdot s\right)+ \\
& +\Delta U_{i n_{-} F B}(s) \cdot \gamma_{1}^{*}+\Delta U_{i n_{-} F B}^{*} \cdot \Delta \gamma_{1}(s) \text {, } \\
& \Delta I_{a}(s)=I_{a}^{*} \cdot \Delta \gamma_{1}(s)+\Delta I_{a}(s) \cdot \gamma_{1}^{*}+\Delta I_{i n_{-} F B}(s)+ \\
& +\Delta U_{\text {in_ } F B} \cdot s \cdot C_{1} \text {, } \\
& \Delta U_{\text {load }}(s)=\left(\Delta U_{\text {in_FB }_{-} F}(s) \cdot \gamma_{2}^{*}+U_{\text {in_FB }_{-} F B} \cdot \Delta \gamma_{2}(s)\right) \cdot n- \\
& -\Delta I_{L 2}(s) \cdot\left(R_{2}+L_{2} \cdot s\right) \text {, } \\
& \Delta I_{\text {in } F B}(s)=\left(\Delta I_{L 2}(s) \cdot \gamma_{2}^{*}+I_{L 2}^{*} \cdot \Delta \gamma_{2}(s)\right) \cdot n \text {, } \\
& \Delta I_{L 2}(s)=\Delta I_{\text {load }}(s)+\Delta U_{\text {load }}(s) \cdot s \cdot C_{2} \text {, } \\
& \Delta U_{a}(s)=\Delta U_{a_{-} I d l}(s)+Z_{a}(s) \cdot \Delta I_{a}(s) \text {, } \\
& \Delta P_{a}(s)=\Delta U_{a}(s) \cdot I_{a}^{*}+\Delta I_{a}(s) \cdot U_{a}^{*}, \\
& \Delta I_{\text {load }}(s)=\Delta U_{\text {load }}(s) / Z_{\text {load }}(s) \text {. }
\end{aligned}
$$
tions

Considering the power stabilization loop closing equa-

$$
\Delta P_{\varepsilon}=\Delta P_{r e f}(s)-\Delta P_{a}(s),
$$

and the stabilization loop of the input voltage of the BTC

$$
\Delta U_{\varepsilon}=\Delta U_{\text {in_ }_{-} F B}(s)-\Delta U_{\text {ref_FB }} F(s),
$$

we will compose the functional diagram of the CDD-LC with closed stabilization loop in the charging mode of the battery (fig. 1).

In the discharge mode of the battery with constant power, it is necessary to change the plus sign to the minus sign in the functional diagram (fig. 1) before the $\Delta U_{a-i d l}$ increment of the open circuit voltage. 


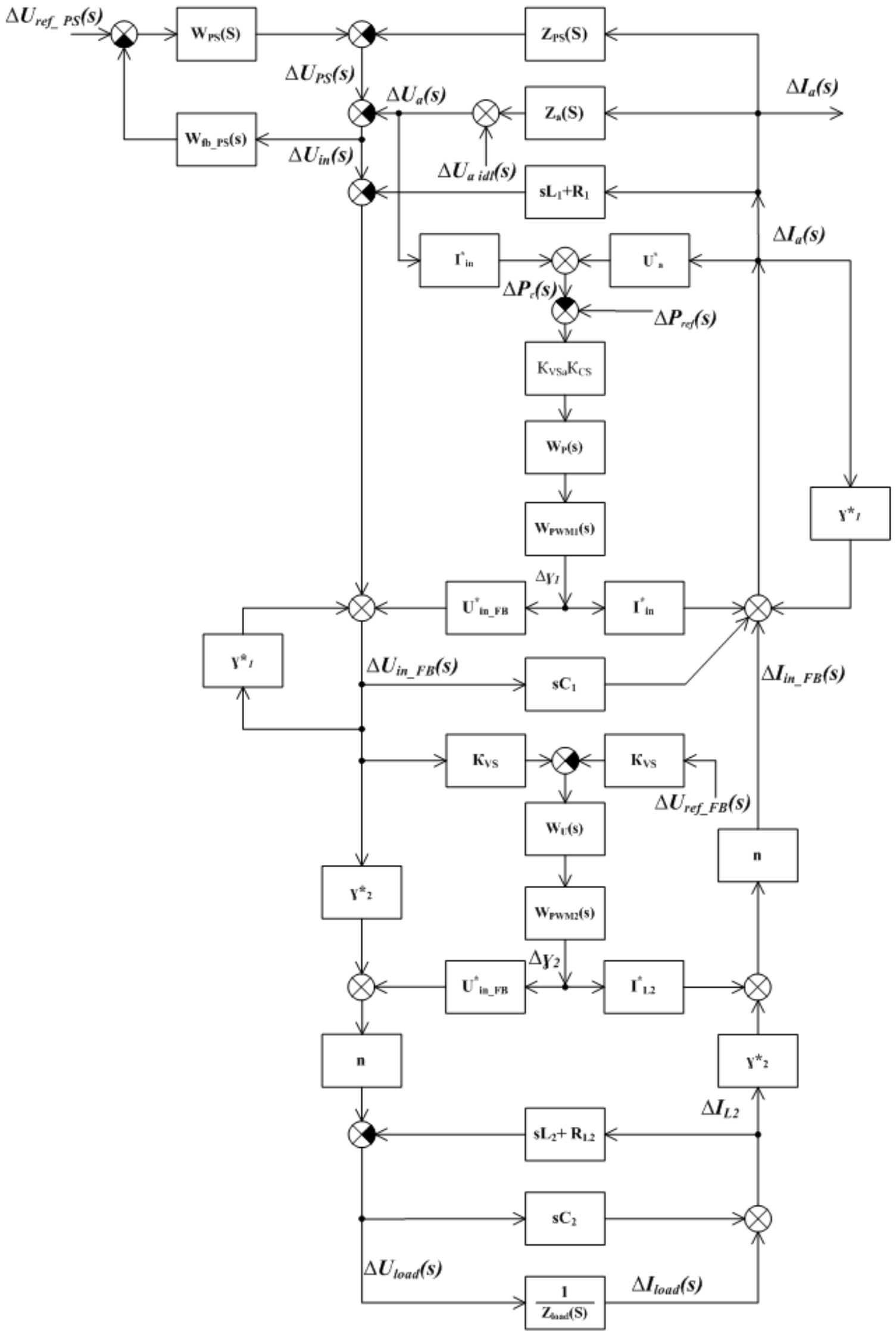

Fig. 1. Functional scheme of CDD-LC linearized model in dynamical mode for LIA constant power stabilization

Рис. 1. Функциональная схема линеаризованной модели ЗРУ-НП-РН в динамическом режиме при стабилизации зарядной мощности аккумулятора 
Resistance of resistors of CDD-LC mathematical model

\begin{tabular}{|c|c|c|c|c|c|}
\hline$R_{P S}, \mathrm{Ohm}$ & $R_{a}, \mathrm{Ohm}$ & $R_{w a}, \mathrm{Ohm}$ & $R_{L 2}, \mathrm{Ohm}$ & $R_{\text {load }}, \mathrm{Ohm}$ & $R_{L 1}, \mathrm{Ohm}$ \\
\hline $9.3 \cdot 10^{-3}$ & $2 \cdot 10^{-3}$ & $3 \cdot 10^{-3}$ & 0.33 & 3 & $5.3 \cdot 10^{-3}$ \\
\hline
\end{tabular}

Values of reactive elements of CDD-LC mathematical model

\begin{tabular}{|c|c|c|c|c|c|c|c|c|}
\hline$L_{P S}, \mu \mathrm{HY}$ & $C_{P S}, \mu F$ & $L_{a}, \mu H Y$ & $L_{w a}, \mu \mathrm{HY}$ & $L_{2}, \mu \mathrm{HY}$ & $C_{2}, \mu F$ & $C_{1}, \mu F$ & $L_{\text {load }}, \mu \mathrm{HY}$ & $L_{1}, \mu \mathrm{HY}$ \\
\hline 11 & 25 & 1.5 & 2 & 60 & 220 & 1050 & 23 & 31.3 \\
\hline
\end{tabular}

Table 3

TF expressions of CDD-LC mathematical model

\begin{tabular}{|c|c|c|c|}
\hline$W_{P S}(s)$ & $W_{f b} P S$ & $W_{P W M I}(s)$ & $W_{P W M 2}(s)$ \\
\hline$\frac{99}{1+s \cdot 1.59 \cdot 10^{-4}}$ & 1 & $3.7 \cdot 10^{-3} e^{-3.3 \cdot 10^{-6} \cdot s}$ & $2.8 \cdot 10^{-4} e^{-12.5 \cdot 10^{-6} \cdot s}$ \\
\hline
\end{tabular}

Expressions of the impedances of CDD-LC mathematical model

\begin{tabular}{|c|c|c|c|}
\hline$Z_{P S}(s)$ & $Z_{a}(s)$ & $Z_{w a}(s)$ & $Z_{\text {load }}(s)$ \\
\hline$R_{P S}+s \cdot L_{P S}$ & $R_{a}+s \cdot L_{a}$ & $R_{w_{-} A}+s \cdot L_{w_{-} a}$ & $R_{\text {lod }}+s \cdot L_{\text {load }}$ \\
\hline $1+s \cdot R_{P S} \cdot C_{P S}+s^{2} \cdot L_{P S} \cdot C_{P S}$ & & \\
\hline
\end{tabular}

To analyze the stability of the power stabilization loop, we find the transfer function (TF) of the open loop (OL)

$$
W_{O L_{-} P}(s)=\Delta P_{a}(s) / \Delta P_{\text {ref }}(s) .
$$

For this reason, in the system of equations (1) we take the zero values of the control input:

$$
\Delta U_{\text {ref_PS }}=0, \Delta U_{\text {ref_FB }}=0, \Delta U_{a_{-} i d l}=0,
$$

open closed loop by power:

$$
\Delta P_{\varepsilon}=\Delta P_{r e f}(s),
$$

and solve the system of equations (1), (3), (4) concerning $\Delta P_{a}(s)$.

To calculate the TF $W_{O L_{P} P}(s)$ parameters, it is necessary to set the initial values of the parameters and coefficients in the equations of the system (1). For a specific implementation of the CDD-LC, the values of the coefficients and parameters for calculating the parameters of the transfer functions of the CDD are summarized in tables 1 to 4 .

According to the calculated logarithmic amplitude $L_{O L_{P} P}(\omega)=20 \mathrm{lg} \cdot \bmod W_{O L_{-} P}(s)$ and phase characteristics (fig. 2), the uncorrected power stabilization loop does not have stability margin, i. e. the loop is unstable.

Current and voltage transients regulated in accordance with the LIA test program should not exceed the limits of the maximum values controlled by the protection system. Therefore, these processes should have the form as close as possible to aperiodic ones with the required rise time $t_{N}$ (the time of the transient change from 10 to $90 \%$ ). For an aperiodic transient, the rise time $t_{N}$ is related to the cutoff frequency $\omega_{c 1}$ by an approximate expression [17]:

$$
t_{N}=(0.3-0.6) \frac{1}{\omega_{c 1}} .
$$

In accordance with the method of V. V. Solodovnikov [17], for an aperiodic transient process, it is necessary to provide a phase margin.

The analysis shows that in order to provide the required stability margin, it is appropriate to include in the functional circuit of the loop a feedforward compensator with a $\mathrm{TF}$ of the following form:

$$
W_{C 1}(s)=\frac{T_{1} \cdot s+1}{T_{2} \cdot s+1},
$$

where $T_{1}=0.0318 \mathrm{~s}$ and $T_{2}=133 \mathrm{~s}$.

In this case corrected OL TF of power stabilization takes the form:

$$
W_{C O L_{-} P}(s)=W_{O L_{-} P}(s) \cdot W_{C 1}(s) .
$$

This corresponds to the frequency characteristics of $L_{\mathrm{COL}_{-} P}(f), \Delta \varphi_{\mathrm{COL}_{-} P}(f)$, shown in fig. 2 .

It can be seen from fig. 2 that when the power is regulated in a wide range, the required stability margins are provided in the loop.

The voltage stabilization loop at the input of the BTC. The voltage of stabilization $U_{\text {мпт }}$ at the input of the BTC is related to the allowed value of the drain-source voltage $U_{d s}$, using transistor switches:

$$
U_{\text {in_FB }} \approx 0,5 \cdot U_{d s},=12 \mathrm{~V} .
$$

Therefore, in transient modes, the voltage overshoot $\sigma_{2}$ is limited, and should not exceed the value $\sigma_{2}=45 \%$.

For the normal operation of the power stabilization and BTC voltage loops, the condition $t_{\sigma 2} \leq t_{\sigma 1}$ must be fulfilled, i. e. the transient time $t_{\sigma 2}$ should not be greater than in the power stabilization loop $\left(t_{\sigma 1} \approx(3-4) t_{N}\right)$. On the basis of the foregoing, we find the frequency $f_{C 2}$ of the cut 
in the voltage stabilization loop (VSL) of BTC from condition

$$
f_{c 2} \leq \frac{2}{t_{\sigma 2}} \approx 4 \pi f_{c 1}
$$

Fig. 2 shows that the frequency $f_{C 1}$ is approximately $200 \mathrm{~Hz}$.

Therefore, the cutoff frequency in the VSL of BTC should be $f_{C 2} \approx 2500 \mathrm{~Hz}$.

To analyze the stability of the BTC voltage stabilization loop, we find the TF of the open loop:

$$
W_{O L_{-} U}(s)=\Delta U_{\text {in_FB }}(s) / \Delta U_{r e f \_} F B(s) .
$$

For this, in the system of equations (1) we take the zero values of the control input: $\Delta U_{\text {ref } P S}=0, \Delta U_{\text {ref } F B}=0$, $\Delta U_{a_{-} i d l}=0$, cut off the voltage feedback:

$$
\Delta U_{\varepsilon}=-\Delta U_{r e f_{-} F B}(s),
$$

and solve the system of equations (1), (3), (4) with respect to $\Delta U_{\text {in } R B}(s)$.

Analysis of the stabilization loop shows that in order to ensure the required margins of stability and speed, it is appropriate to include in the functional circuit of the loop a feedforward compensator calculated by the method of V. V. Solodovnikov [17], with the TF of the following form:

$$
W_{C 2}(s)=\frac{\left(T_{3} s+1\right) \cdot\left(T_{4} \cdot s+1\right)}{\left(T_{5} \cdot s+1\right) \cdot\left(T_{6} \cdot s+1\right)},
$$

where $T_{3}=3.18 \cdot 10^{-5} \mathrm{~s}$, and $T_{4}=3.18 \cdot 10^{-4} \mathrm{~s}, T_{5}=3.18 \cdot 10^{-3} \mathrm{~s}$ and $T_{6}=3.18 \cdot 10^{-6} \mathrm{~s}$

In this case, the corrected OL TF stabilizing the voltage takes the form:

$$
W_{A O L_{-} U}(s)=W_{\mathrm{OL}_{-} U}(s) \cdot W_{C 2}(s) .
$$

This expression of the $\mathrm{TF}$ corresponds to the frequency characteristics of $L_{\mathrm{COL}_{-} U}(f), \Delta \varphi_{\mathrm{COL} U} U(f)$, $\Delta \varphi_{C O L} U(f)$, given in fig. 3 .

It is evident from fig. 3: power control in a wide range in a loop provides necessary margins of stability; when medium and high power are stabilized, the requirements for the cut-off frequency $f_{C 2}$ of the VSL of BTC are fulfilled with a margin, and when the low-power charge/discharge LIA is stabilized, the decrease in the frequency $f_{C 2}$ does not lead to an increase in the voltage overshoot $\sigma_{2}$ due to the relatively small charge currents of the capacitor at the input of the BTC.

The change in the dynamic properties of the VSL of BTC can lead to a change in the dynamic properties of the PSL of LIA associated with it. To verify compliance with previously established requirements for the stability and speed of the PSL, $L_{C O L_{-} P}(f), \Delta \varphi_{C O L_{-} P}(f)$ were recalculated taking into account the correction of both loops and the results are shown in fig. 4 .

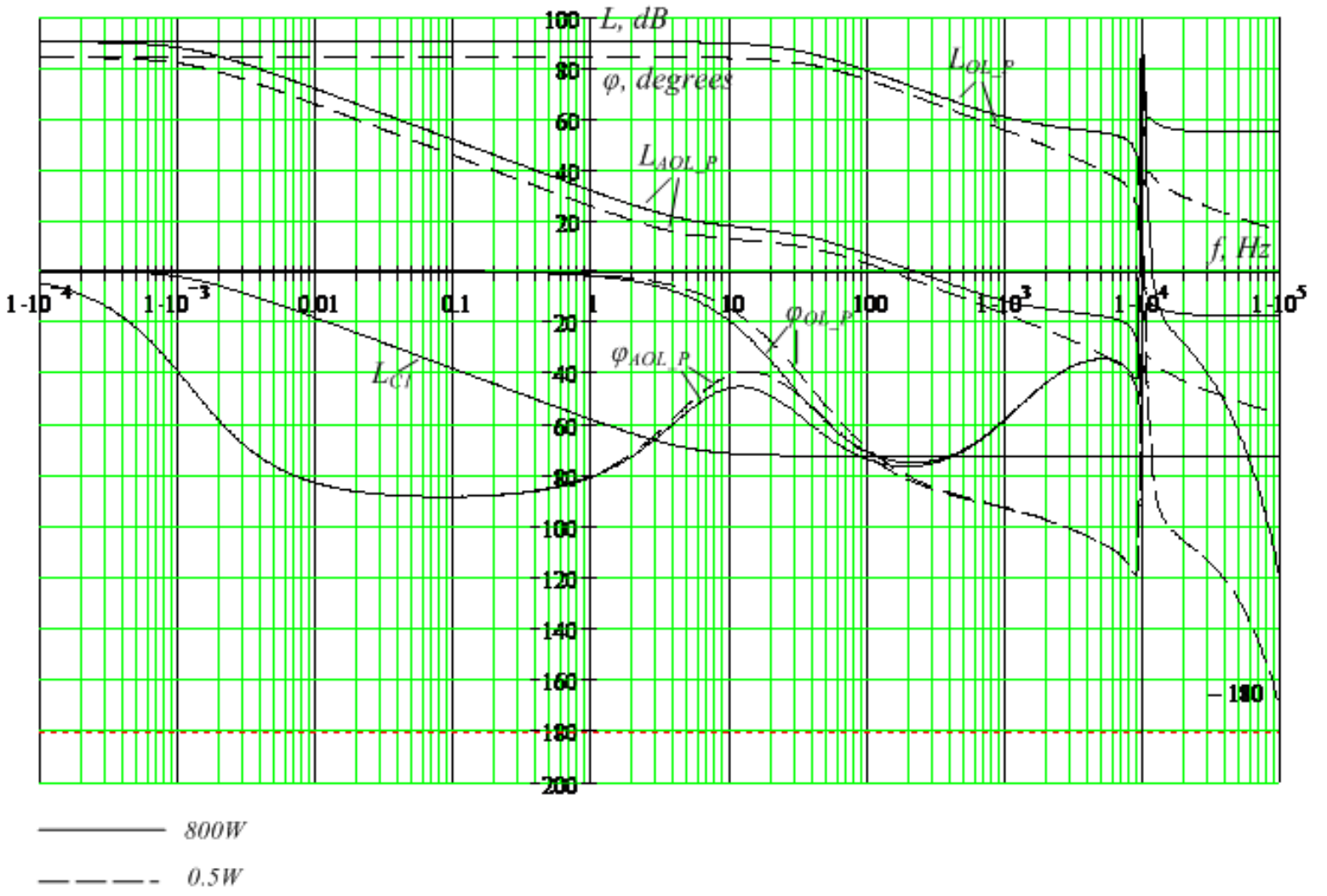

Fig. 2. Open loop Bode plot of CDD while charging LIA with constant power

Рис. 2. Частотные характеристики разомкнутого контура ЗРУ-НП при заряде ЛИА постоянной мощностью 


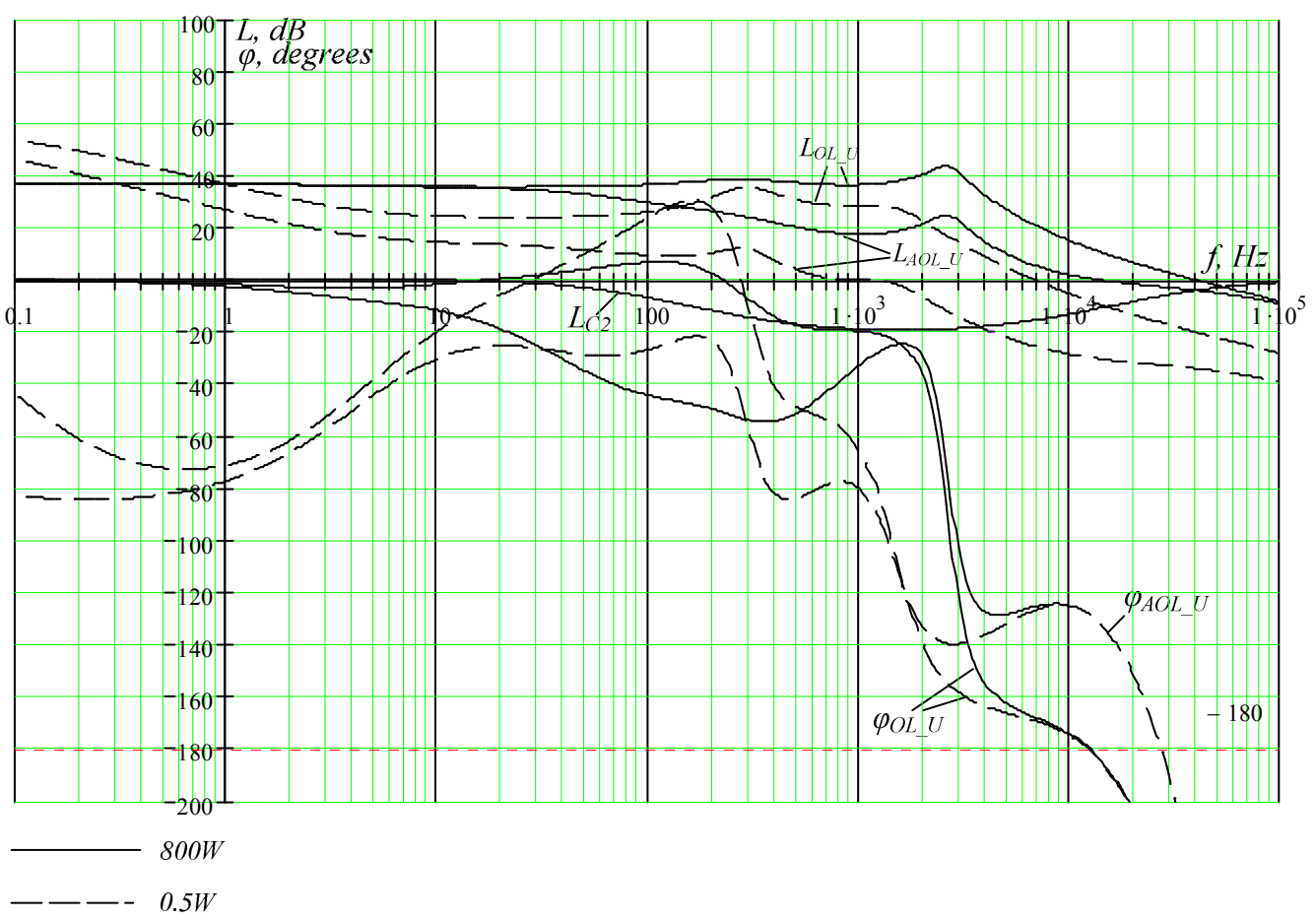

Fig. 3. Open loop Bode plot for $W_{O L_{-} U}(s)$ in LIA constant power mode

Рис. 3. Частотные характеристики разомкнутого контура стабилизации напряжения $W_{O L_{-} U}(s)$ при стабилизации мощности аккумулятора

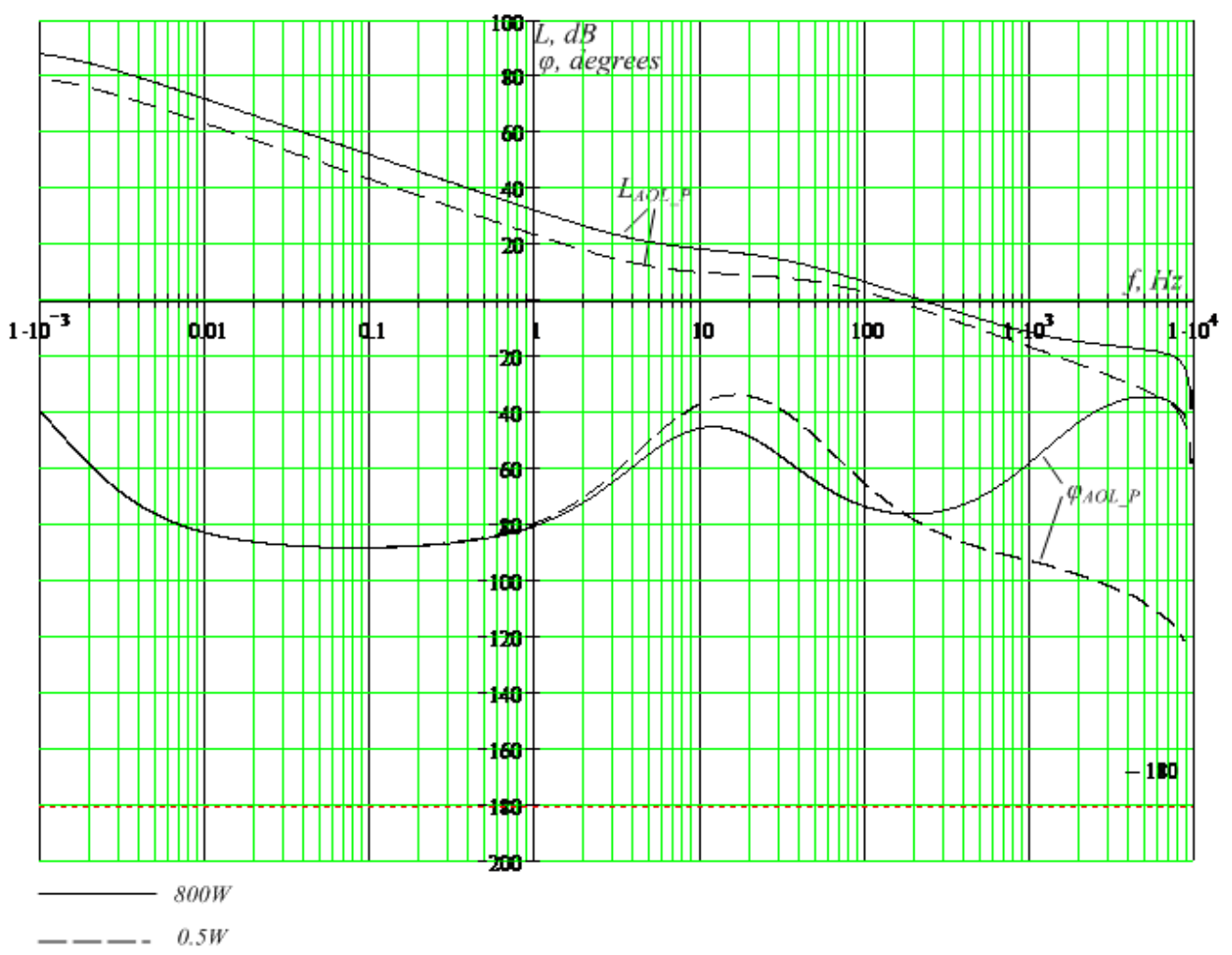

Fig. 4. Corrected open loop Bode plot of CDD model for $W_{C O L_{-} P}(s)$

Рис. 4. Частотные характеристики скорректированного разомкнутого контура ЗРУ-НП при заряде ЛИА постоянной мощностью 
The FC of $L_{A O L P}(f)$ и $\varphi_{A O L P}(f)$ (fig. 4) corrected PSL charge/discharge of the LIA when controlling the powers in a wide range have the phase margins $\Delta \varphi_{1} \geq 100^{\circ}$ and the cutoff frequency $f_{c 1}$ in the frequency range of $200 \mathrm{~Hz}$, which meets the requirements.

Absolute stability. In the regime of charge/discharge power stabilization, the current-voltage characteristic (I-V characteristic) of a CDD-LC is non-linear, due to the presence of nonlinear (functional) feedback on the power of the LIA

$$
P_{a}(t)=U_{a}(t) \cdot I_{a}(t)
$$

Since the parameters of the functional feedback vary with time, the CDD-LC in the power stabilization mode is a non-linear non-stationary automatic control system (ACS).

For the stability analysis of such systems, it is appropriate to apply the method developed by B. N. Naumov and Ya. Z. Tsypkin [18-20]. This method requires bringing the ACS to a single-circuit view (fig. 5), containing a stable dynamic linear part (LP) and one static nonlinear element (NE). The criterion allows one to judge the stability of the ACS by the frequency characteristics of the LP system and the differential coefficient $k_{N E \max }$ of the NE transmission.

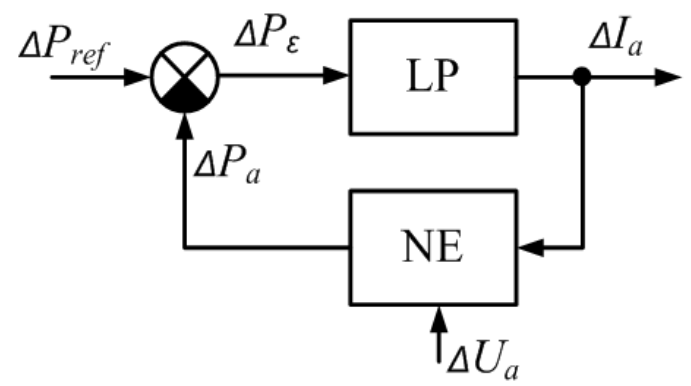

Fig. 5. Single-circuit view of the ACS: LP - linear part, $\mathrm{NE}$ - non-linear element

Рис. 5. Одноконтурный вид САУ: ЛЧ - линейная часть, НЭ - нелинейный элемент

In the case of a nonstationary system, B. N. Naumov and Ya. Z. Tsypkin showed [18-20] that the processes in the system will be asymptotically stable in general if the criterion of absolute stability is satisfied at the highest value of the differential coefficient $k_{N E \max }$ of NE transmission.

The main output variable of the CDD is the current $I_{a}(t)$ of the LIA, which when the power is stabilized varies depending on the voltage of the LIA $U_{a}$, which according to (1) has the form:

$$
U_{a}(s)=U_{a_{-} I d l}(s)+Z_{a}(s) \cdot I_{a}(s) .
$$

The equation of a nonlinear element:

$$
P_{a}\left(I_{a}\right)=\left(U_{a_{-} i d l}+R_{a} \cdot I_{a}\right) \cdot I_{a} \cdot K_{C S} \cdot K_{V C A} \cdot K_{P},
$$

where $K_{p}-$ coefficient of proportionality.
The linear part of the power stabilization open loop is described by a system of equations:

$$
\begin{aligned}
& \left(\Delta U_{P S}(s)=\left(\Delta U_{r e f_{-} P S}(s)-\Delta U_{i n}(s) \cdot W_{f b_{-} P S}(s)\right) \times\right. \\
& \times W_{P S}(s)-Z_{P S}(s) \cdot \Delta I_{a}(s) \text {, } \\
& \Delta U_{i n}(s)=\Delta U_{P S}(s)-\Delta U_{a}(s)-Z_{a}(s) \cdot \Delta I_{a}(s), \\
& \Delta \gamma_{1}(s)=\Delta P_{r e f}(s) \cdot K_{C S} \cdot K_{V S a} \cdot W_{P}(s) \cdot W_{P W M 1}(s), \\
& \Delta \gamma_{2}(s)=\left(\Delta U_{\text {in } F B}(s)-\Delta U_{\text {ref } F B}(s)\right) \cdot K_{V S} \cdot W_{U}(s) \cdot W_{P W M 2}(s) \text {, } \\
& \Delta U_{\text {in } F B}(s)=\Delta U_{\text {in }}(s)-\Delta I_{a}(s) \cdot\left(R_{L 1}+L_{L 1} \cdot s\right)+ \\
& +\Delta U_{i n_{-} F B}(s) \cdot \gamma_{1}^{*}+\Delta U_{i n_{-} F B}^{*} \cdot \Delta \gamma_{1}(s), \\
& \Delta I_{a}(s)=I_{a}^{*} \cdot \Delta \gamma_{1}(s)+\Delta I_{a}(s) \cdot \gamma_{1}^{*}+\Delta I_{\text {in_FB }}(s)+ \\
& +\Delta U_{\text {in_FB }} \cdot s \cdot C_{1} \text {, } \\
& \Delta U_{\text {load }}(s)=\left(\Delta U_{\text {in } F B}(s) \cdot \gamma_{2}^{*}+U_{\text {in } F F}^{*} \cdot \Delta \gamma_{2}(s)\right) \cdot n- \\
& -\Delta I_{L 2}(s) \cdot\left(R_{2}+L_{2} \cdot s\right) \text {, } \\
& \Delta I_{\text {in } F B}(s)=\left(\Delta I_{L 2}(s) \cdot \gamma_{2}^{*}+I_{L 2}^{*} \cdot \Delta \gamma_{2}(s)\right) \cdot n \text {, } \\
& \Delta I_{L 2}(s)=\Delta I_{\text {load }}(s)+\Delta U_{\text {load }}(s) \cdot s \cdot C_{2} \text {, } \\
& \Delta U_{a}(s)=\Delta U_{a \text { Idl }}(s)+Z_{a}(s) \cdot \Delta I_{a}(s), \\
& \Delta P_{a}(s)=\Delta U_{a}(s) \cdot I_{a}^{*}+\Delta I_{a}(s) \cdot U_{a}^{*}, \\
& \Delta I_{\text {load }}(s)=\Delta U_{\text {load }}(s) / Z_{\text {load }}(s) \text {. }
\end{aligned}
$$

To analyze the absolute stability of the power stabilization loop, we find the TF of the linear part of the open loop

$$
W_{O L_{-} L P}(s)=\Delta I_{a}(s) / \Delta P_{\text {ref }}(s),
$$

and LPC $L_{O L_{-} L P}(s,) \varphi_{O L_{-} L P}(s)$ (fig. 6).

According to Naumov-Tsypkin criterion [18-20], for absolute stability of processes in a control system with nonstationary NE it is sufficient that the LP should be stable and the frequency response of the LP should satisfy all frequencies $0 \leq \omega \leq \infty$ the condition:

$$
\operatorname{Re}\left(W_{O L_{-} L P}(j \omega)\right)+\frac{1}{k_{N E \max }}>0
$$

or:

$$
\operatorname{Re}\left(k_{N E \max } W_{O L_{-} L P}(j \omega)\right)>-1 .
$$

Denoting the TF by modified LP (MLP),

$$
W_{\mathrm{MLP}}(j \omega)=k_{N E \max } W_{O L_{-} L P}(j \omega),
$$

we obtain the condition of absolute stability processes in the form:

$$
\operatorname{Re}\left(W_{\text {MLP }}(j \omega)\right)>-1,
$$

where the maximum differential transmission coefficient of NE:

$$
k_{N E \max }=\left(\frac{\partial P_{a}}{\partial I_{a}}\right)_{\mathrm{MAX}} .
$$

In accordance with (6), the coefficient $k_{N E}$ is a function of three independent variables: the input current $I_{a}$, the open circuit voltage $U_{a \text { idl }}$, the internal resistance $R a$ of the battery.

Let us study the ranges of $k_{N E}$ coefficient variation depending on these parameters. 
It follows from fig. 7 that the coefficient $k_{N E}$ reaches its maximum value at the maximum current $I_{a}$, voltage $U_{a \text { idl }}=4,2 \mathrm{~V}$ and resistance $R_{a}=20 \mathrm{mOhm}$, with $k_{N E \_ \text {MAX }} \leq 12$.

Graphical interpretation of condition (7) means that the amplitude-phase characteristic (APC) of the MLD (fig. 8) should lie to the right of the vertical line passing through the point with the coordinates $(-1 ; 0)$.
Since the frequency characteristics (FC) LP of the CDD-LC (fig. 8) depends on the value of the stabilized power, the analysis of the absolute stability of the processes must be performed for the entire range of power regulation $P_{a}$. As a result of APC MLP analysis it was stated that it is sufficient to check the absolute stability with minimum and maximum LIA test power values (fig. 8).

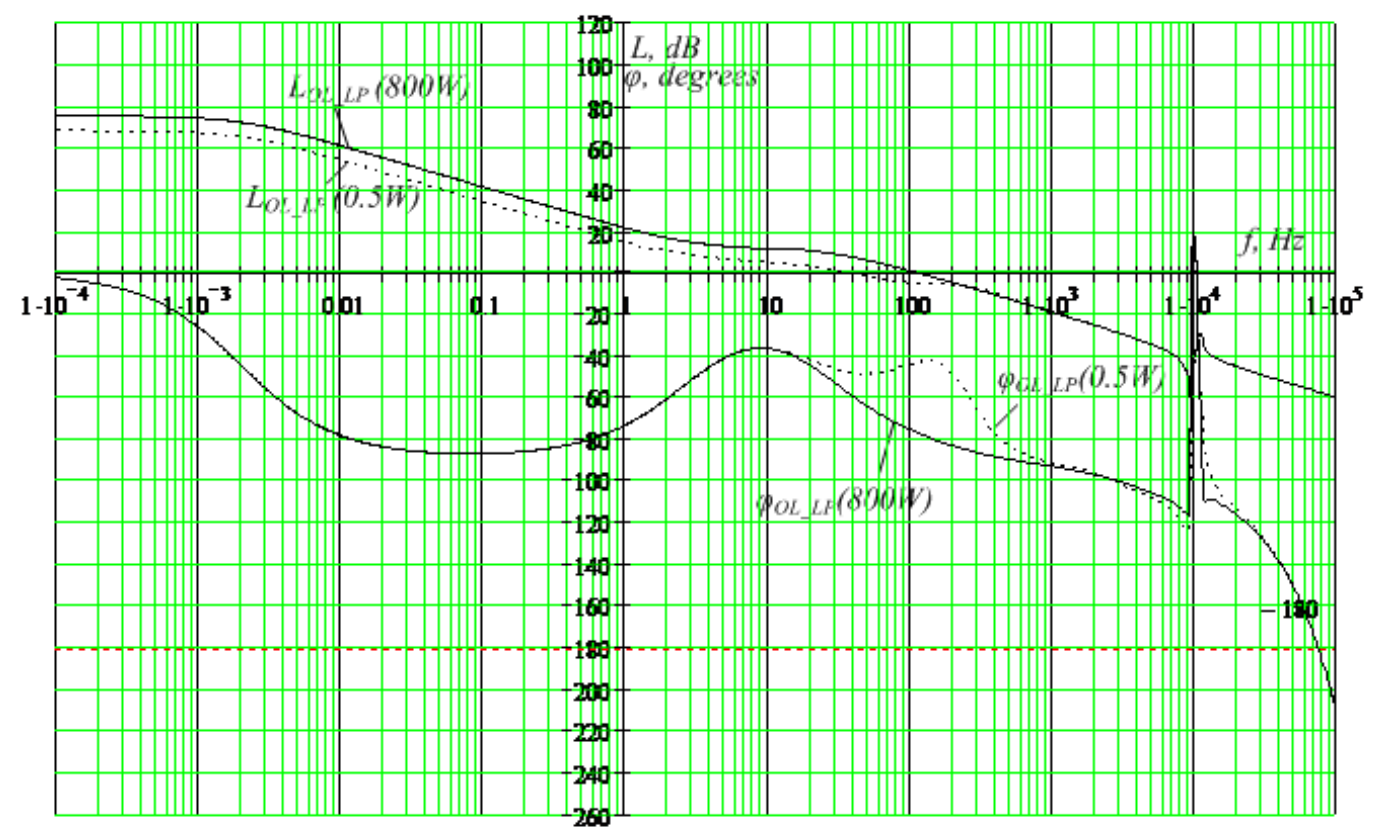

Fig. 6. Bode plot of open-loop linear part (OL_LP)

Рис. 6. Частотные характеристики разомкнутого контура линейной части (ЛЧ)

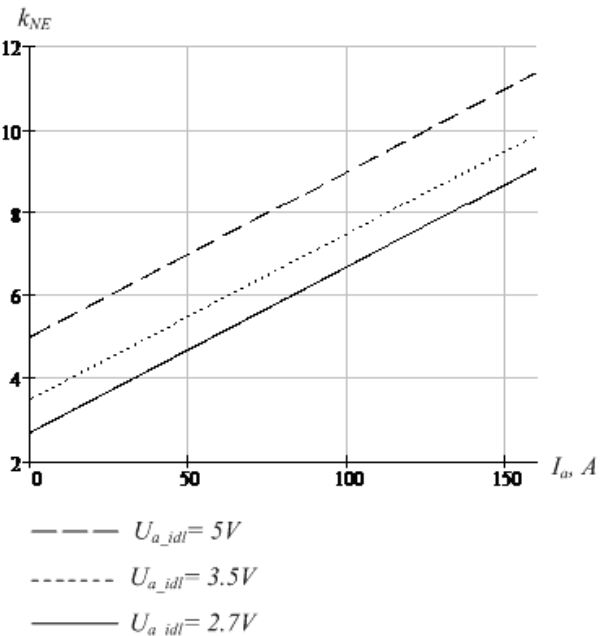

$a$

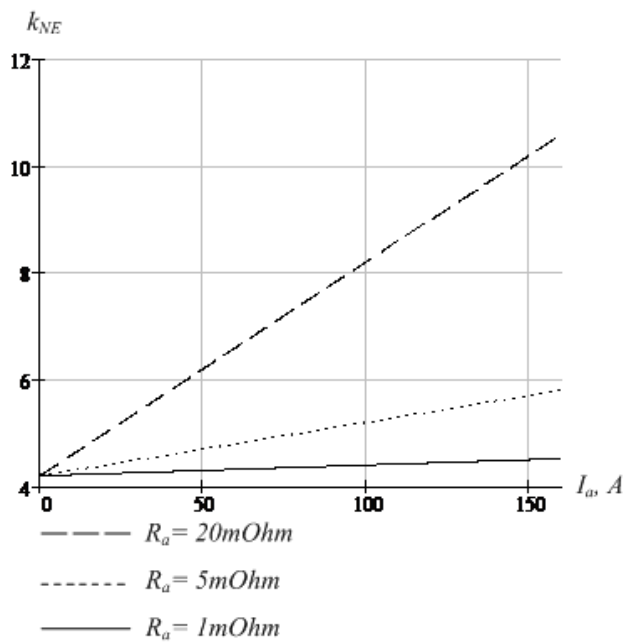

$b$

Fig. 7. Dependence of the coefficient $k_{N E}\left(I_{a}\right)$ on: $a$-different voltages $U_{a}$ idl and resistance $R_{a}=20 \mathrm{mOhm} ; b$-different resistance $R_{a}$ and voltage $U_{a_{-} i d l}=4,2 \mathrm{~V}$

Рис. 7. Зависимость коэффициента $k_{\mathrm{HЭ}}\left(I_{\mathrm{Bx}}\right): a$ - при различных напряжениях $U_{a x x}$ и сопротивлении $R_{a}=20$ мОм; $\sigma$ - при различных сопротивлениях $R_{a}$ и напряжении $U_{a x x}=4,2 \mathrm{~B}$ 

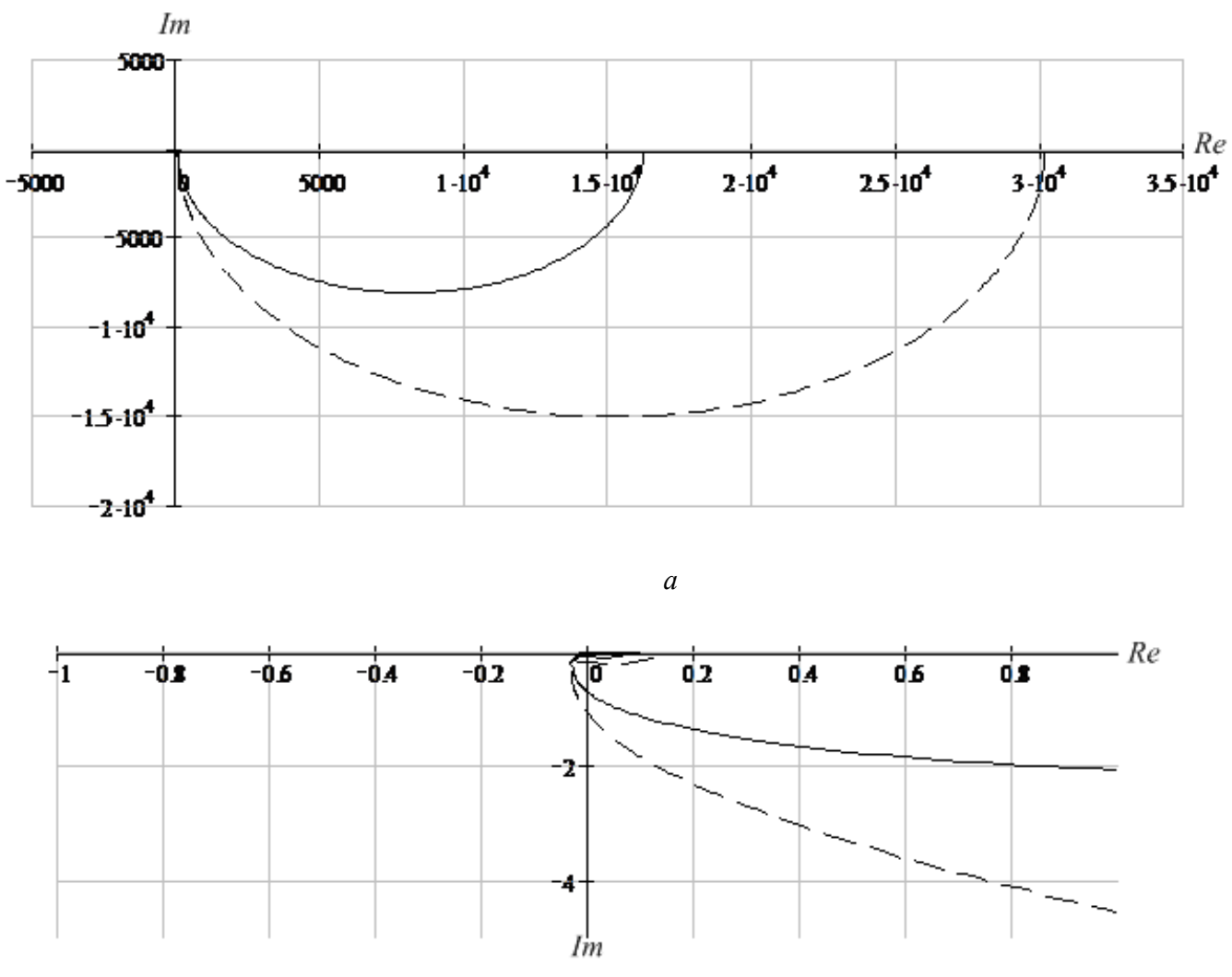
$0.5 \mathrm{~W}$

$b$

$--800 \mathrm{~W}$

Fig. 8. Amplitude phase characteristic $W_{M L D}(j \omega)$ for $k_{N E}=12$ : $a$ - for the frequency range $0 \leq \omega \leq 10^{5}$, $b-$ in the field of high frequencies (in the vicinity of the point $(-1 ; j \cdot 0)$ )

Рис. 8. Амплитудно-фазовая характеристика $W_{\text {млч}}(j \omega)$ при $k_{\mathrm{H \ni}}=12: a-$ для диапазона частот $0 \leq \omega \leq 10^{5}$; $\sigma$ - в области высоких частот (в окрестности точки $(-1 ; j \cdot 0))$

It follows from APC (fig. 8):

1. For the calculated and selected parameters of the MLD $W_{M L D}(j \omega)$ linear part, the condition of absolute processes stability (7) is fulfilled irrespective of the power value $P_{a}$ of the LIA charge/discharge.

2. The hodographs APC MLD $W_{M L D}(j \omega)$ at the maximum and minimum input powers differ in the interval of low and medium frequencies and practically coincide in the high-frequency interval, determining the absolute stability of the CDD-LC control system, which indicates the correctness of the synthesis of correcting devices (4) and (5).

To prove the adequacy of the developed mathematical models, the experimental sample of the CDD-LC module was investigated.

To obtain transient control processes with power stabilization, the experiment scheme shown in fig. 9 was used. In the tests, instead of the LIA, a test load was used that allowed to estimate the operation in large ranges of currents and voltages of the CDD.

When testing, direction of current when charging the battery is taken for a positive current direction. Fig. 10 shows the process of changing the voltage $U_{\text {in } F B}$ at the input of the BTC (upper graph of the oscillogram) and the current of the battery $I_{a}$ (lower graph of the oscillogram) with a linear discharge power surge of the battery from $P_{3}=3 \mathrm{~W}$ to $P_{3}=640 \mathrm{~W}$. At the same time, the rate of battery power surge is $V_{\mathrm{I}}=350 \mathrm{~A} / \mathrm{s}$. Sweep trace of the voltage channel $U_{\text {in } F B}$ corresponds to $5 \mathrm{~V} / \mathrm{div}$ (fig. 10) and $80 \mathrm{~A} / \mathrm{div}$ for channel measurement of current $I_{a}$. Time sweep trace $-100 \mathrm{~ms} /$ div

It can be seen from fig. 10 that the current deviation from the linear character differs slightly, and the excessive correction of $\sigma_{2}$ voltage $U_{B T C}$ does not exceed $42 \%$, which meets the requirements for the value of $\sigma_{2}$.

Conclusion. The developed mathematical model of electromagnetic processes of the CDD-LC in the charge/discharge LIA power stabilization mode allows to analyze and synthesize CDD-LC with the required control power stabilization loop quality indicators.

Control system of the CDD-LC is presented in the form of two interrelated control loops: power stabilization loop, and the input voltage stabilization loop of the bridging transformer converter. It is shown that it is appropriate to adjust the power stabilization loop first, and then, taking into account the data obtained, select the parameters of the BTC voltage stabilization loop correcting device. 


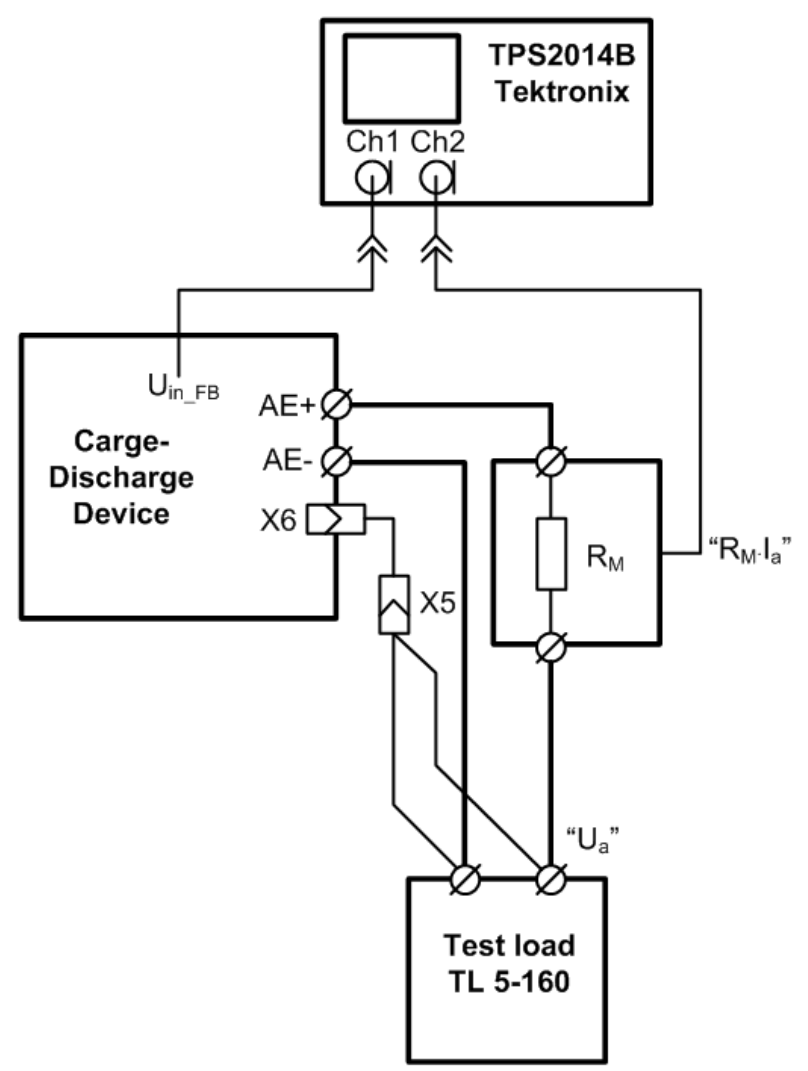

Fig. 9. Transient response experiment test structure

Рис. 9. Схема эксперимента для снятия переходных процессов по управлению

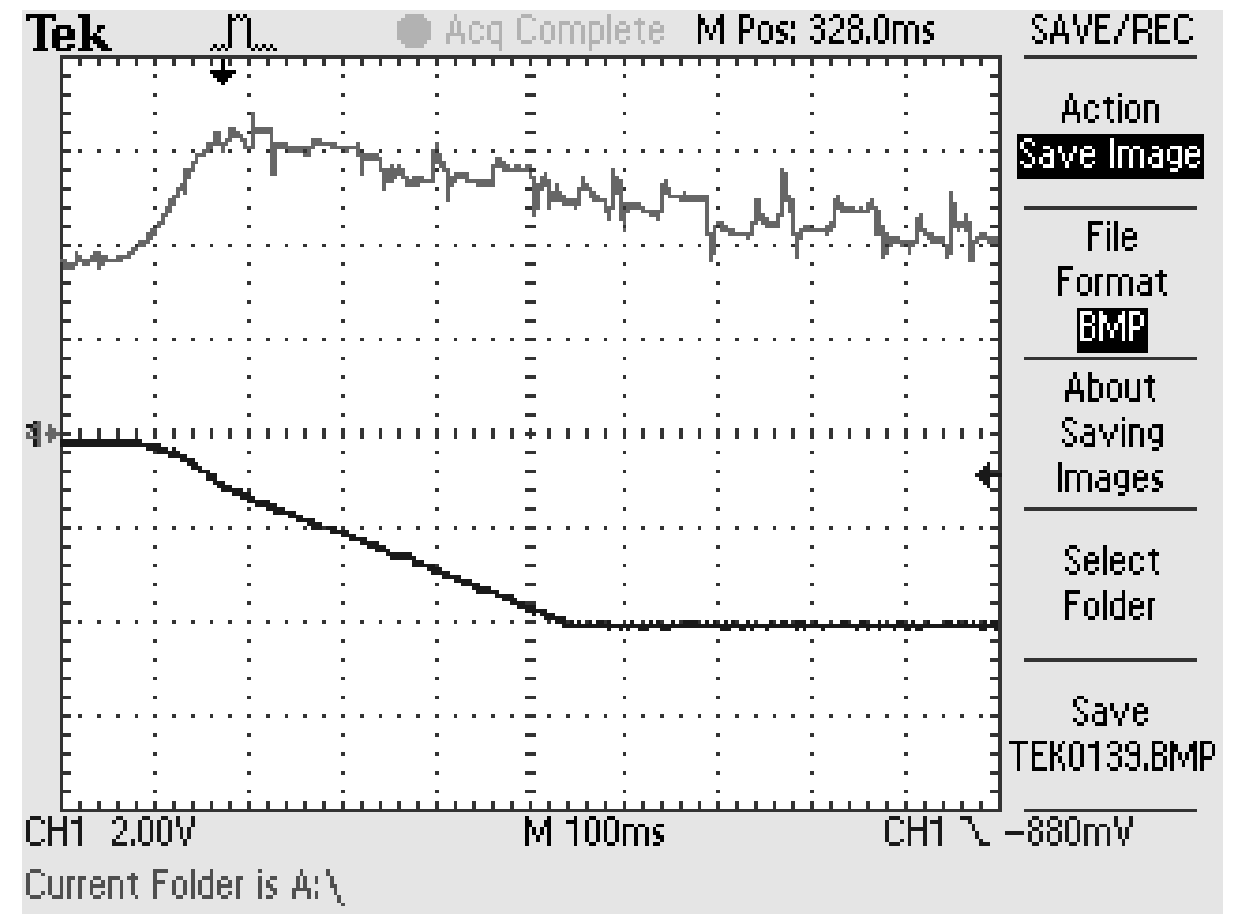

Fig. 10. Transients for linearly increasing power

Рис. 10. Переходные процессы при линейном увеличении разрядной мощности 
The proposed type of correcting devices allows to ensure absolute stability of processes in the CDD-LC when stabilizing the charge/discharge power of LIA with the required speed and quality of transients.

The experimentally obtained transients meet the necessary requirements, which confirms the adequacy of the CDD-LC mathematical model with the stabilization of the LIA power.

\section{References}

1. GOST R MEK 61427-1-2014. Akkumulyatory i akkumulyatornyye batarei dlya vozobnovlyayemykh istochnikov energii. Obshchiye trebovaniya i metody ispytaniy. CHast' 1. Primeneniye v avtonomnykh fotoelektricheskikh sistemakh [Secondary cells and batteries for renewable energy storage. General requirements and methods of test. Part 1. Photovoltaic off-grid application]. Moscow, Standartinform Publ., 2014. 13 p.

2. GOST R MEK 62660-1-2014. Akkumulyatory litiyionnyye dlya elektricheskikh dorozhnykh transportnykh sredstv. CHast' 1. Opredeleniye rabochikh kharakteristik [Secondary lithium-ion cells for the propulsion of electric road vehicles. Part 1. Performance testing]. Moscow, Standartinform Publ., 2015. 29 p.

3. Mizrakh E. A., Kopylov E. A., Nesterishin M. V. et al Ustroystvo dlya ispytaniya akkumulyatornogo elementa [Battery cell testing equipment]. Patent RF, No. 123530, 2012.

4. Mizrakh E. A., Lobanov D. K., Kopylov E. A. et al Preobrazovatel' napryazheniya [Voltage converter]. Patent RF, No. 153595, 2015.

5. Fedchenko A. S., Kopylov E. A., Lobanov D. K. et al. Static accuracy of the automated stand for lithiumion batteries testing. 18th Mediterranean Electrotechnical Conference (MELECON), 2016, April 18-20. DOI:10.1109/MELCON.2016.7495336.

6. Fedchenko A. S., Kopylov E. A., Lobanov D. K. Mizrah E. A. Static Accuracy of the Lithium-Ion Battery Automated Test Bench. 2016 International Siberian Conference on Control and Communications (SIBCON). ISBN: 978-1-4673-8383-7/16.

7. Fedchenko A. S., Kopylov E. A., Lobanov D. K. et al. Study of a lithium-ion battery charge-discharge test unit characteristics. IOP Conf. Series: Materials Science and Engineering 122 (2016) 012015. DOI: $10.1088 / 1757-899 X / 122 / 1 / 012015$.

8. Peter A. Gottlieb, Rodger B. Dowdell, Jr. Battery communication system. Patent US, No. 6274950 B1, 2001.

9. Narayana Prakash Saligram, Sreejakumar Sreekantan Nair, Ramakrishnan Madenoor Krishnan et al. Battery charging method and apparatus. Patent US, No. 8581554 B2, 2013.

10. James Thommes, Robert W. Johnson Jr., William J. Raddi. Uninterruptible power supplies with dualsourcing capability and methods of operation thereof. Patent US, No. 6160722 A, 2000.

11. Concha P., Vélez P., Lafoz M., Arribas J. R. Flexible low-cost system to test batteries and ultracapacitors for electric and hybrid vehicles in real working conditions. World Electric Vehicle Symposium and Exhibition
(EVS27). Barcelona, 2013, P. 1-11. DOI: 10.1109/EVS.2013.6914771.

12. Jo H., Cha H. Parallel operation of three-phase bidirectional isolated interleaved DC-DC converters for battery test system. IEEE Applied Power Electronics Conference and Exposition - APEC 2014, Fort Worth, TX. 2014, P. 1584-1589. DOI: 10.1109/APEC.2014.6803518

13. Mizrah E. A., Lobanov D. K., Kopylov E. A. et al. On the Static Accuracy of Charge-Discharge Units Intended for Electrical Tests of High Capacity Li-ion Batteries. IOP Conference Series: Materials Science and Engineering, International Siberian Conference Reshetnev Readings. 2016. DOI: 10/1088/1757899X/255/1/012016.

14. Fedchenko A. S., Kopylov E. A., Lobanov D. K. An automated charge-discharge unit for electrical tests of individual high capacity lithium-ion battery cells. 2015 International Siberian Conference on Control and Communications (SIBCON). Proceedings. Omsk, Omsk State Technical University. Russia, Omsk, May 21-23, 2015. IEEE Catalog Number: CFP15794-CDR.

15. Kotelnikov V. A. On the carrying capacity of the ether and wire in telecommunications, Material for the First All-Union Conference on Questions of Communication. Moscow, Red. Upr. Svyazi RKKA Publ., 1933.

16. Bryant B., Kazimierczuk M. K. Open-loop powerstage transfer functions relevant to current-mode control of boost PWM converter operating in CCM, Circuits and Systems I: Regular Papers. IEEE Transactions. 2005, Vol. 52, No. 10, P. 2158-2164.

17. Solodovnikov V. V. Osnovy avtomaticheskogo regulirovaniya teoriya [Fundamentals of automatic regulation. Theory]. Moscow, Gosudarstvennoe nauchnotekhnicheskoe izdatel'stvo mashinostroitel'noy literatury Publ., 1954, 1120 p.

18. Tsypkin Ya. Z. Osnovy teorii avtomaticheskikh system [Fundamentals of automatics system theory]. Moscow, Nauka Publ., 1977, 560 p.

19. Vavilov A. A. Chastotnyye metody rascheta nelineynykh sistem [Frequency analysis of nonlinear systems]. Leningrad, Energiya Publ., 1970, 324 p.

20. Naumov B. N. Teoriya nelineynykh avtomaticheskikh sistem. Chastotnyye metody [Frequency methods in the theory of nonlinear automatic systems]. Moscow, Nauka Publ., 1972, 544 p.

\section{Библиографические ссылки}

1. ГОСТ Р МЭК 61427-1-2014. Аккумуляторы и аккумуляторные батареи для возобновляемых источников энергии. Общие требования и методы испытаний. Ч. 1. Применение в автономных фотоэлектрических системах. М. : Стандартинформ, 2014. 13 с.

2. ГОСТ Р МЭК 62660-1-2014. Аккумуляторы литий-ионные для электрических дорожных транспортных средств. Ч. 1. Определение рабочих характеристик. М. : Стандартинформ, 2015. 29 с.

3. Пат. 123530 Российская Федерация, МПК G 01 N 27/416. Устройство для испытания аккумуляторного элемента / Мизрах Е. А., Копылов Е. А., Нестеришин М. В., Козлов Р. В., Лобанов Д. К. ; заявитель и патентообладатель Сиб. гос. аэрокосмич. ун-т. № 2012127508 ; заявл. 02.07.12 ; зарег. 27.12.12. 
4. Пат. 153595 Российская Федерация, МПК Н 02 M 3/335, Н 02 M 3/337, Н 02 M 3/28, Н 02 M 3/24. Преобразователь напряжения / Мизрах Е. А., Лобанов Д. К., Федченко А. С., Копылов Е. А. ; заявитель и патентообладатель СибГАУ имени академика М. Ф. Решентнева. № 2014147920 ; заявл. 27.11.14 ; зарег. 30.06.15.

5. Static accuracy of the automated stand for lithiumion batteries testing / A. S. Fedchenko [et al.] // 18th Mediterranean Electrotechnical Conference (MELECON). 2016, April 18-20.

6. Fedchenko A. S., Kopylov E. A., Lobanov D. K., Mizrah E. A. Static Accuracy of the Lithium-Ion Battery Automated Test Bench // International Siberian Conference on Control and Communications (SIBCON). 2016.

7. Study of a lithium-ion battery charge-discharge test unit characteristics / A. S. Fedchenko [et al.] // IOP Conf. Series: Materials Science and Engineering. 2016. 122. 012015. DOI: $10.1088 / 1757-899 X / 122 / 1 / 012015$.

8. Пат. 6274950 В1 США, МПК Н 02 J 7/00, H 02 J 9/06, G 01 R 31/36. Battery communication system / Gottlieb P. A., Dowdell R. B. Jr. № 08/205,527 ; заявл. 03.03.94; опубл. 14.08.01.

9. Пат. 8581554 В2 США, МПК Н 02 J 7/00. Battery charging method and apparatus / Narayana Prakash Saligram, Sreejakumar Sreekantan Nair, Ramakrishnan Madenoor Krishnan, Milind Dighrasker. № 12/500,877 ; заявл. 10.07.09; опубл. 12.11.13.

10. Пат. 6160722 А США, МПК Н 02 М 7/12, H 02 M 5/458, H 02 J 9/06. Uninterruptible power supplies with dual-sourcing capability and methods of operation thereof / James Thommes, Robert W. Johnson, Jr., William J. Raddi. № 09/401,423 ; заявл. 22.09.99; опубл. 12.12.00.

11. Concha P. Flexible low-cost system to test batteries and ultracapacitors for electric and hybrid vehicles in real working conditions [Электронный pecypc]. URL: http://ieeexplore.ieee.org/iel7/6902670/6914705/ 06914771.pdf (дата обращения: 24.05.2018).

12. Jo H. and Cha H. Parallel operation of threephase bi-directional isolated interleaved DC-DC convert- ers for battery test system // IEEE Applied Power Electronics Conference and Exposition - APEC 2014. 2014. P. 1584-1589.

13. On the Static Accuracy of Charge-Discharge Units Intended for Electrical Tests of High Capacity Liion Batteries / E. A. Mizrah, [et al.] // IOP Conference Series: Materials Science and Engineering, International Siberian Conference. Reshetnev Readings-2016. 2016. DOI: 10/1088/1757-899X/255/1/012016.

14. Fedchenko A. S., Kopylov E. A., Lobanov D. K. An automated charge-discharge unit for electrical tests of individual high capacity lithium-ion battery cells // International Siberian Conference on Control and Communications (SIBCON). Proceedings (Omsk, May 21-23). Omsk : Omsk State Technical University, 2015. IEEE Catalog Number: CFP15794-CDR.

15. Kotelnikov V. A. On the carrying capacity of the ether and wire in telecommunications // Material for the First All-Union Conference on Questions of Communication, Izd. Red. Upr. Svyazi RKKA. M., 1933.

16. Bryant B. and Kazimierczuk M. K. Open-loop power-stage transfer functions relevant to current-mode control of boost PWM converter operating in CCM, Circuits and Systems I: Regular Papers // IEEE Transactions on. 2005. Vol. 52, No. 10. P. 2158-2164.

17. Основы автоматического регулирования: теория / В. В. Солодовников [и др.] ; под. ред. В. В. Солодовникова. М. : Государственное научно-техническое издательство машиностроительной литературы, 1954. $1120 \mathrm{c.}$

18. Цыпкин Я. З. Основы теории автоматических систем. М. : Наука. Главная редакция физико-математической литературы, 1977. 560 с.

19. Вавилов А. А. Частотные методы расчета нелинейных систем. Л. : Энергия, 1970. 324 с.

20. Наумов Б. Н. Теория нелинейных автоматических систем. Частотные методы. М. : Наука. Главная редакция физико-математической литературы, $1972.544 \mathrm{c}$.

(C) Kopylov E. A., Lobanov D. K., Mizrakh E. A., 2018 